\title{
Introducing career skills for dental students as an undergraduate course at the University of Szeged, Hungary
}

\author{
Réka Magdolna Szabó ${ }^{1}$, Joan Mary Davis ${ }^{2}$ and Márk Antal ${ }^{3^{*}}$ (D)
}

\begin{abstract}
Background: In the last three decades there is a growing recognition in the dental profession that dental education must go beyond teaching the technicalities of dentistry and include professionalism and communication skills that the future dentist may need. Such skills are best taught in a student-centered way. Literature suggests that student-centered elements are difficult to introduce in traditional, teacher-centered curricula. This is especially true in post-communist countries where higher education was under strict state control for decades. The aim of the piece of research presented here was to investigate how difficult it is to introduce a student-centered career skills course in a traditionally teachercentered dental curriculum.
\end{abstract}

Methods: Considering the needs of our final-year dental students and Super's model of career development, we created an undergraduate curricular career skills course running for two semesters in two languages (Hungarian and English). The primary aim of the course is to help students with their career expectations and develop their identity as a professional workforce. The secondary aim is to teach skills that students can use when applying for a job. At the end of the semesters, we assessed our students' satisfaction with various aspects of the course by using a questionnaire. Results were analyzed item-wise and according to the main aspects of the course (i.e., groups of items organized around a particular aspect).

Results: General satisfaction with the course was high, and practical skills training (such as CV and motivation letter writing) got the highest scores. From the answers it appears that the students were the least comfortable with having to deal with their personal values and preferences.

Conclusions: While it is common for universities to offer various forms of career intervention, to our knowledge, no other university offers a curricular career skills course specifically for dental students. Our student-centered course designed in a problem-based learning framework worked even in a traditionally teacher-centered educational environment, where university students are rarely encouraged to be active participants in courses. By sharing our experience, we would like to encourage our fellow dental educators working in similar environments to devise and offer such courses.

Keywords: Dentistry, Career development, Problem-based learning, Curriculum

\footnotetext{
*Correspondence: antal.mark@stoma.szote.u-szeged.hu

${ }^{3}$ Department of Esthetic and Operative Dentistry, University of Szeged,

Faculty of Dentistry, Tisza Lajos körút 64, Szeged 6720, Hungary

Full list of author information is available at the end of the article
}

(c) The Author(s). 2020 Open Access This article is licensed under a Creative Commons Attribution 4.0 International License, which permits use, sharing, adaptation, distribution and reproduction in any medium or format, as long as you give appropriate credit to the original author(s) and the source, provide a link to the Creative Commons licence, and indicate if changes were made. The images or other third party material in this article are included in the article's Creative Commons licence, unless indicated otherwise in a credit line to the material. If material is not included in the article's Creative Commons licence and your intended use is not permitted by statutory regulation or exceeds the permitted use, you will need to obtain permission directly from the copyright holder. To view a copy of this licence, visit http://creativecommons.org/licenses/by/4.0/ The Creative Commons Public Domain Dedication waiver (http://creativecommons.org/publicdomain/zero/1.0/) applies to the data made available in this article, unless otherwise stated in a credit line to the data. 


\section{Background}

The undergraduate dental curriculum "should prepare graduates to enter practice" [1]. What it means depends on what is considered practice-related by a given curriculum. Literature and most importantly experience tell us, though, that dentistry is a particularly demanding profession that requires a wide range of non-clinical skills. As Myers and Myers summarized, 'It's difficult being a dentist' [2]. This is partly because of the plethora of health hazards [3-7], but also because of the difficulties in balancing work and family [8] and the fact that dentists need to be competent also in non-medical aspects of their practice, such as financial planning, addressing legal issues, personal time management, or practice organization. Studies have found that both dentists and dental students tend to find such practical matters challenging [9]. It should come as no surprise that dentists are exposed to high levels of stress, and none of the specialties seems to be an exception [10]. Constant stress paves the way for alcohol problems [11], burnout [12], and, in the most severe cases, suicide [13]. Accordingly, dental schools around the world have started to address these issues in their curricula. Dealing with the non-strictly professional challenges of dentistry, however, requires certain 'soft' skills (e.g. communication, knowledge of one's self, etc.) that cannot be taught in a teacher-centered framework.

Introduction of a student-centered approach, however, can be difficult. Resistance to change in higher education is a well-known phenomenon [14], toward which both faculty and students contribute. Analyzing the reasons on the faculty side, Brickner differentiated between firstorder and second-order barriers to change [15]. The former category includes extrinsic factors, such as insufficient time to plan instruction or inadequate support, and the latter includes intrinsic ones, like beliefs about teaching and learning, strong adherence to established classroom practices or, simply, unwillingness to change $[16,17]$. Students, on the other hand, are often socialized to be and used to being passive recipients of academic information [18]. Jain et al. [19] point out that 'teaching in most Asian countries is still dominated by teachercentered classrooms, in which students passively receive information from the teacher and internalize it through memorization'. The authors add that while such students may find an active role uncomfortable, they often find the passive way of learning unsatisfactory. In summary, the wish for change may well be present together with resistance to it.

Several dental curricula, however, still prepare graduates predominantly in the technical sense, while crucial aspects of dentistry as a job are paid only cursory attention. Cerych, summarizing the situation right after the fall of the Soviet Union, pointed out that the rigid centralization and almost total political control of higher education turned resistance to change into the normal state of affairs in the occupied Central European countries. As the author laconically remarks, "...the majority of people in higher education in Central Europe do not know how to do things differently. They are naturally aware of, and even adhere to, general concepts such as university autonomy or freedom of teaching, but too often these are merely postulates without practical consequences. Worse, they may be postulates leading to problematic simplifications [...] a new curriculum meaning just getting rid of the ideological constraints, without moving toward new structures of knowledge." Then he goes on to cite a Czechoslovak specialist: "One of the greatest problems is that the majority of teachers are not interested in curriculum change" [14]. Almost 30 years after the democratic turn, the situation looks quite similar, at least in Hungary. What conserved this attitude of resistance and the old structures as a consequence is a complex issue, the discussion of which is clearly beyond the scope of this paper. Still, its pervasive presence is a fact. At the same time, the literature of medical education and international experience suggest that the introduction of student-centered elements is imperative to enhance the quality of dental education [20-22].

What we present here is a curricular career intervention course for senior (5th -year) students that we introduced into the undergraduate dental curriculum at the Faculty of Dentistry, University of Szeged, Hungary in the academic year $2017 / 2018$. The course was approved by the Faculty Council (Decision No. 4/2017 (2017.01.31.)).

Given the described educational atmosphere, we initially assessed our students' opinion about this more student-centered way of teaching and the contents of the course with the help of a questionnaire (see below). Our hypothesis was that the course would be generally welcome by students, and the practical aspects of it would be the most popular. We also hypothesized that other aspects, especially having to talk about one's strengths and weaknesses, would be less appreciated, as they are unusual for a university course and generally alien from the educational culture our students were socialized in.

\section{The educational context}

In Hungary, dentistry is a 10-semester master's program. The four universities that offer dentistry (Budapest, Szeged, Debrecen, and Pécs) have different curricula, but these are all organized around the same main phases or modules: foundations (basic medical sciences and social sciences related to medicine, such as ethics and medical psychology), preclinical studies (laboratory work and the basics of the most frequent dental interventions), and clinical studies (treatment of patients under supervision). 
Students obtain their DMD degree after the successful completion of written and oral state board examination. At this point, they are also immediately licensed and registered as general dental practitioners by the National Public Health and Medical Officer Service. Thus, it is possible for the newly graduated dentist to start practice immediately. Those who wish to keep their right to practice must participate in continuing education. Other options include specialty training (3-4 years at university clinics or licensed private practices), $\mathrm{PhD}$ studies (4 years), or any job that requires a dental degree. The path to a career in dental education usually starts with specialty training and typically continues with $\mathrm{PhD}$ studies, as a $\mathrm{PhD}$ in clinical medicine is a requirement for promotion beyond assistant professor. Dental educators in the clinical studies stage of the undergraduate curriculum are always practicing dentists.

Career counseling or support is not part of the curriculum at any level. Such activities are mostly organized in an extracurricular fashion. The University of Szeged, for instance, has a Career Office, which organizes job fairs and provides an online advertising surface for firms offering jobs, but - unfortunately - career counseling is not part of the office's portfolio. Furthermore, this service has no profession-specific elements, so the specific needs of dental students are not addressed at all.

It was in this context that we designed and introduced the course delineated here. Our initiative was that as dental educators, we found that our senior students were often at a loss when faced with the reality of having to choose a career and enter the job market. Some of them did not have any idea about what careers were possible with a dental degree apart from chairside work, but we often met students who had not even thought about their career before the end of their studies. Our goal was to help these students at this critical point. Here we describe the course and our initial experiences with it, with an emphasis on student feedback.

\section{Methods}

\section{Aims of the course}

In terms of career development, the course sets out aims at multiple levels. To formulate our aims, we used Donald Super's theory of career development as a framework [23, 24]. In Super's career lifespan, university students fall into the specification (18 to 21 years of age) and implementation (22 to 24 years of age) substages of the exploration stage (15 to 24 years of age). The goals linked to these substages are career planning, training for the specific goals, and career initiation. Strictly speaking, fifth year dental students (aged 22-23 years) fall into the implementation substage. However, Super's model of career development as a model of linear development built of consecutive stages could work only in a system that actively supports the accomplishment of every stage. The real situation is not so clear-cut. Hur and colleagues demonstrated how different medical students can be in terms of how ready they are for a career [25]. We had similar experiences. Therefore, we decided to add aims to address the entire exploration stage, including also the crystallization substage (15 to 17 years in the original model). The main reason for including that early substage was that dentistry opens the way toward various career tracks (as mentioned above), of which chairside work is but one. We assumed that our students did not have that information in high school, when they went through their "first" crystallization stage, and we wished to give them the chance to briefly revisit that substage with the new information in mind. This is of vital importance, as the goal of this substage is the self-assessment of one's needs, values, competencies, and opportunities. Without that, no sound career decision is possible.

The primary aim of the course is to help students with their career expectations and develop their identity as a professional workforce. The secondary aim is to teach skills that students can use when applying for a job. After completing this course, students should be able to write a CV and motivation letter, prepare their own professional portfolio, and assess if a potential workplace meets their character, goals, and expectations. The rationale for this is twofold: first, it has been documented that organizing background materials, practicing answers, and doing one's own research on potential employers could improve the outcomes of a job interview [26]. Second, activities related to the secondary aim also contribute to the primary aim. Detailed study goals are presented in Table 1.

\section{Course design}

The course consists of three consecutive phases, and the various activities included address the different substages in Super's exploration stage, as described above. The phases and tasks related to the substages are shown in Table 1.

The first phase consists of introductory lectures about job options and opportunities available for the newly graduated dentist. These lectures provide detailed information about specialization as well as about working as a private dentist versus a state employee (or a combination of the two). Emphasis is placed on the personal attitudes, skills, and abilities that students need to find their place in the settings discussed above. Although the primary goal of these lectures is to familiarize students with local (Hungarian) characteristics, an overview of key differences between EU member states and some overseas countries, such as the United States and Australia is also provided. While focusing on a well- 
Table 1 Course structure

\begin{tabular}{|c|c|c|c|c|}
\hline $\begin{array}{l}\text { Addressed career } \\
\text { development } \\
\text { substage }\end{array}$ & Topic/Activity & Study goal & Allocated time & Course phase \\
\hline $\mathrm{CR}$ & Opportunities as a fresh graduate & $\begin{array}{l}\text { The student knows about his or her opportunities } \\
\text { as a fresh graduate (including dental work) }\end{array}$ & $1 \mathrm{~h}$ & TP/C \\
\hline$C R$ & Career options as a dentist & $\begin{array}{l}\text { The student knows about his or her opportunities } \\
\text { specifically linked to the dental degree }\end{array}$ & $1 \mathrm{~h}$ & TP/C \\
\hline$C R$ & $\begin{array}{l}\text { Assessment of personal character traits, } \\
\text { strengths and weaknesses }\end{array}$ & $\begin{array}{l}\text { The student has a fundamental career-related } \\
\text { concept of himself or herself as a person }\end{array}$ & $2 \mathrm{~h}$ & TP/C \\
\hline IMP & $\begin{array}{l}\text { Study sample CVs to demonstrate main } \\
\text { points of CV writing }\end{array}$ & $\begin{array}{l}\text { The student knows the formal and stylistic } \\
\text { requirements of a professionally written CV }\end{array}$ & $2 \mathrm{~h}$ & TP/C \\
\hline SP & $\begin{array}{l}\text { Coaching in career planning (optional, } \\
\text { by appointment) }\end{array}$ & $\begin{array}{l}\text { The student has personalized feedback on his } \\
\text { or her actual career dilemmas }\end{array}$ & $1 \mathrm{~h} /$ student & TP/C \\
\hline IMP & Preparation of own CVs (extra-class) & $\begin{array}{l}\text { The student has a formally and content-wise } \\
\text { correct CV }\end{array}$ & NA & PP \\
\hline IMP & $\begin{array}{l}\text { Motivation letter and professional } \\
\text { portfolio samples }\end{array}$ & $\begin{array}{l}\text { The student knows what (not) to include in a } \\
\text { motivation letter and portfolio }\end{array}$ & $1 \mathrm{~h}$ & PP \\
\hline IMP & $\begin{array}{l}\text { Preparation of own motivation } \\
\text { letter (extra-class) }\end{array}$ & The student has a motivation letter & NA & PP \\
\hline IMP & $\begin{array}{l}\text { Evaluation of CVs in group, suggestions, } \\
\text { corrections }\end{array}$ & $\begin{array}{l}\text { The student can critically analyze a CV and use } \\
\text { this knowledge to enhance his or her own CV }\end{array}$ & $1 \mathrm{~h}$ & PP \\
\hline IMP & $\begin{array}{l}\text { Evaluation of motivation letter in group, } \\
\text { suggestions, corrections }\end{array}$ & $\begin{array}{l}\text { The student can critically analyze motivation letter } \\
\text { and use this knowledge to enhance his or her } \\
\text { own motivation letter }\end{array}$ & $1 \mathrm{~h}$ & PP \\
\hline $\mathrm{CR} / \mathrm{SP}$ & Making career decisions & $\begin{array}{l}\text { The student can identify short- and long-term } \\
\text { goals (vs. consequences) and think consciously } \\
\text { about a career decision }\end{array}$ & $1 \mathrm{~h}$ & PP \\
\hline SP & $\begin{array}{l}\text { Establishment of short- and long- } \\
\text { term goals }\end{array}$ & $\begin{array}{l}\text { The student can set well-defined career goals and } \\
\text { expectations for himself or herself }\end{array}$ & $2 \mathrm{~h}$ & PP \\
\hline IMP & Simulated interview (individual) & $\begin{array}{l}\text { The student has prepared for a job interview-like } \\
\text { situation and tried what it feels like to be interviewed } \\
\text { for a job }\end{array}$ & $4 \mathrm{~h}$ & IP \\
\hline SP & Assessment of possible workplaces/jobs & $\begin{array}{l}\text { The student knows how to gather information about } \\
\text { a potential workplace/position and how to assess } \\
\text { that information }\end{array}$ & $1 \mathrm{~h}$ & IP \\
\hline IMP & Job fair & $\begin{array}{l}\text { The student meets real employers, has a chance to } \\
\text { apply for jobs }\end{array}$ & $4 \mathrm{~h}$ & IP \\
\hline
\end{tabular}

Legend- TP/C: theoretical preparation/contemplation; PP: practical preparation; TO: task to be completed outside the class IP: implementation practice; CR: crystallization; SP: specification; IMP: implementation (Career development substages from Super's model, see Methods)

defined topic, these lectures are also interactive and flexible in many ways. First, the students are actively involved, they can ask tquestions any time, or even change the direction of the lecture within the limits of the topic. Second, students have the chance to ask the lecturer to incorporate information about specific settings, countries, etc. of interest into the lecture that follows. This way, each student group can finetune the lectures to their own needs and interests. Third, dental professionals are regularly invited as guests (either in person or via Skype), so participants can gain more personal experience and impressions. The general aim of this theoretical preparatory phase is to support "re-crystallization", that is, to help students set realistic career expectations by providing adequate information and role models.
The second phase, practical preparation, focuses on $\mathrm{CV}$ and motivation letter writing as key skills necessary for a successful job application. The characteristics of the genres are explained, and samples are provided. As an extra-class assignment, students must prepare their own CV and motivation letter. The instructor is actively involved in the writing process by giving feedback on the draft versions and recommending changes if necessary. The primary aim of this phase is not to teach these genres but to provide a chance for students to think about their character and goals and to go through their strengths and weaknesses. The resulting "inventory" not only helps the individual student to think about what to communicate when first applying for a job, but also to identify an apparently optimal starting point for his/her career. As the course is announced for students in their 
final year, CVs and motivation letters prepared here can directly be used.

In the third phase, students finalize their $\mathrm{CV}$ and motivation letter, and individual mock job interviews are video-recorded. The recordings are then evaluated by students and teachers together. We chose interview simulation because interview is the most frequently used and most highly weighted employee selection method, and evidence suggests that interview performance can be efficiently improved via coaching and feedback [27-29]. In the same phase, the course culminates in a job fair, which is a real-life, semi-formal encounter between the participants of the course and various local employers. Employers are invited to register if they are interested in employing newly graduated dentists. The event is organized at the end of the semester, usually at a popular local off-university meeting place, so personal encounters between students and the representatives of employers can take place in a neutral environment. The representatives of the employers have the CVs and motivation letters of the students, and they can talk to those whose introduction they like. The session has no strict rules. The students may also initiate conversation with the employers of their choice. Such a session lasts 3 to 5 $h$ and is best described as a social event with a welldefined purpose.

An optional, individual, sixty-minute coaching session is also part of the course. This is done by appointment. Although this session is optional, every participant has taken the opportunity so far.

The course is taught by a two-person team: an experienced dental educator (who is also a practicing dentist, MA) and a health and marketing communication specialist (RAS).

Student evaluation is based on participation, class activity, and the quality of the prepared materials. A fivepoint grade system is used, where 1 means failed and 5 means excellent.

The number of participants is limited to 15 students/ semester/language (the course is held in English and in Hungarian, see below).

Finally, the course is optional but with a credit value; completion of the course counts toward the completion of dental studies.

The course components and their contribution to the aims of the course are summarized in Fig. 1.

\section{Participants}

So far two semesters have been completed and 39 students have finished the course (12 men and 27 women). The mean age of the participants was $24.6( \pm 2.3)$ years. All students were in their fifth (final) year at the Faculty of Dentistry, University of Szeged. As the Faculty offers dental education in two languages (Hungarian and
English), this course was also held in these two languages. Of the 39 students, 28 attended the Hungarian course (mean age: $23.9 \pm 1.3$ years) and 11 attended the English course (mean age: $26.4 \pm 3.2$ years). Participants of the English course came from 7 different countries (both EU and non-EU countries).

\section{Student feedback}

A short anonymous questionnaire about the course and its methodology was administered to all participants to assess the reception of the course. The questionnaire was approved by the Institutional Review Board at the University of Szeged. The questionnaire consisted of 20 items, of which the first two were demographic in nature (gender and age). The rest were statements, which the students had to evaluate on a 5-point Likert scale (1strongly disagree, 2- disagree, 3- neither agree nor disagree, 4- agree, and 5- strongly agree). Two of the 18 statements were negative controls to check for the validity of answers. The statements aimed to assess five main aspects: general impression, satisfaction with the course (2 items); personal development ( 4 items); CV/motivation letter/portfolio (5 items); career development techniques (e.g., assessment of potential employers, 4 items); job fair (3 items). Each statement was characterized by a mean score (with standard deviation).

Mean scores were calculated as the simple arithmetic mean of the individual scores given by each student (1 to 5). A higher mean, therefore, represents higher average agreement with the given statement (except for the negative controls). An initial ANOVA indicated no significant difference between Hungarian and Englishspeaking students in any of the items (at $p<0.05$ ), therefore the two groups were analyzed together. This method of data analysis was preferred, as Hungarian students predominated in our sample $(\sim 72 \%)$, which made a separate analysis meaningless. The item-wise summary of the results is presented in Table 2. Results were also evaluated by question sets (i.e., regarding the five main aspects described above) by calculating the grand mean of all items. Results of the aspect-wise analysis are shown in Fig. 2. Calculations were done in SPSS 21.0 (IBM, USA).

As the course is new, it is difficult to assess whether the course influences success in finding a job or job satisfaction. Therefore, we focus on student feedback on the course itself, which is an important indicator of how effective the course is, and how well it fits into the curriculum. Obviously, if students find a course useful, interesting, and well-constructed, the efficacy of that course in terms of knowledge transfer increases.

Our hypothesis was that the course would be generally welcome by students (high mean scores on positive items). 


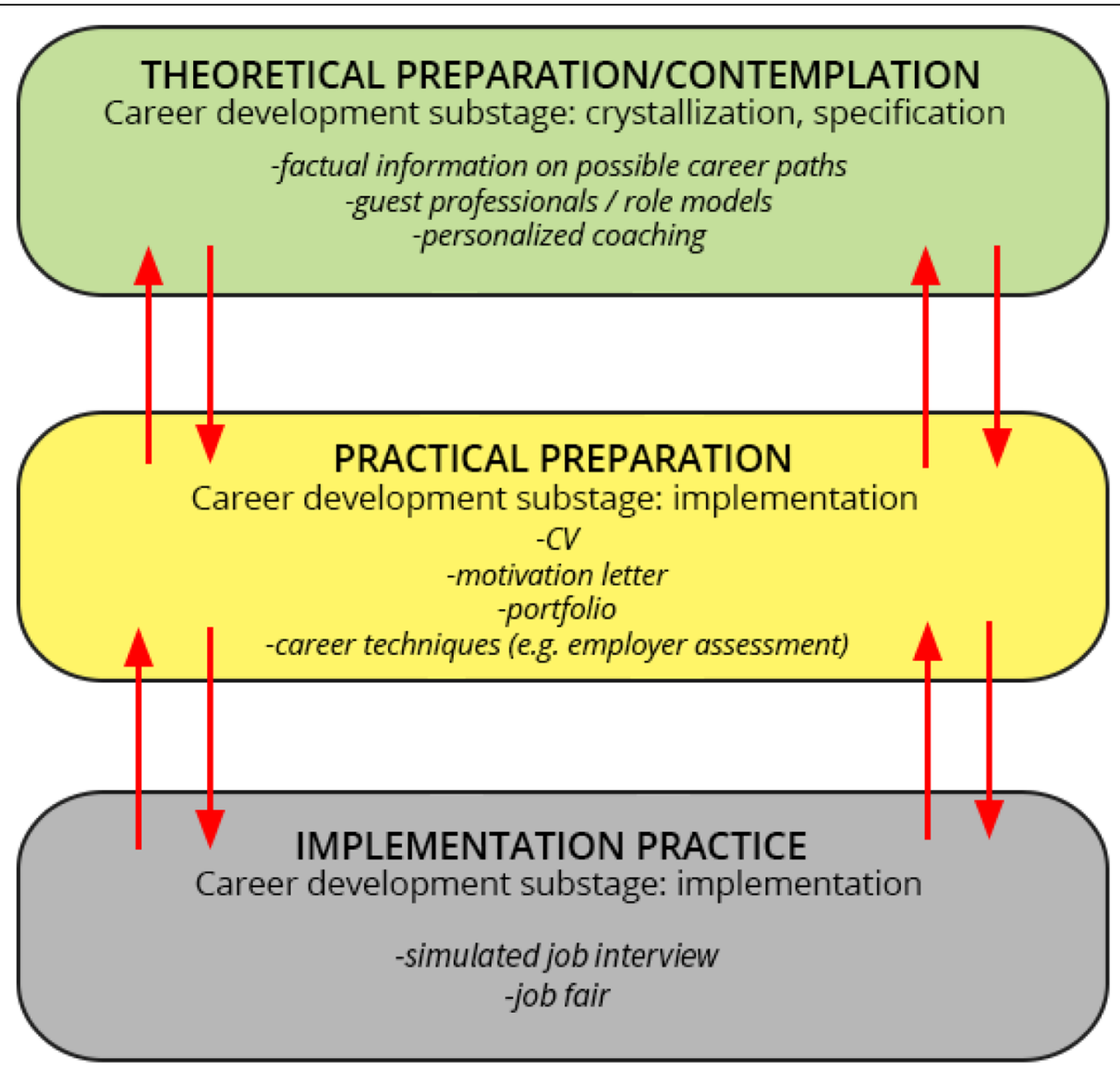

Fig. 1 Components of the course and their interaction. The theoretical preparation/contemplation phase supports the crystallization and specification substages. By offering factual information, showing models and reflecting on the student as a professional who is about to enter the job market, the phase aims at helping students find a job they can identify with. The practical preparation and implementation practice phases both support the implementation substage. The motivation letter and CV have dual purpose: they help the student identify the path he or she wishes to take, but later these can also be used for actual job applications. The mock job interview (with feedback) help students reflect on their self-promotion skills in an interview situation and offers starting points for enhancement if necessary. The portfolio is a material means of selfpromotion that the students can use for job application, just like the CV and motivation letter prepared in the course. The arrows indicate that the phases can influence each other in both ways

\section{Results}

The results are shown in Table 2 and Fig. 2. As for the item-wise results (Table 2), most statements received a mean score above 4 (agree or strongly agree), which indicates a high level of general satisfaction with the course. These results confirmed our main hypothesis. Standard deviations were low with two notable exceptions, item \#10 $(4.03 \pm 1.197)$ and item \# 16 (3.77 \pm 1.459$)$. These items ask the respondent about the perceived effect of feedback on the simulated interview and if he/she has found a potential employer during the job fair, respectively.

Negative statements \#3 and \#9 received a mean score below 2 , indicating that participants did not find having to think and talk about their own personality excessively uncomfortable, and they did not consider knowledge about how to assess a potential employer useless (the latter was control question for item \#6). The results, therefore, did not confirm our hypothesis regarding the personal/psychological aspect, but standard deviation of the mean of item \#3 (1.77) was almost 1.0, which is the third highest standard deviation.

Results of the aspect-wise analysis are presented in Fig. 2 in an increasing order of grand means. All studied aspects scored between 4 and 5, but an order is clear. The general satisfaction aspect got the highest grand mean, which again supports our main hypothesis. As for the particular aspects, practical matters, such as $\mathrm{CV}$ writing, composition of a motivation letter, and other career techniques earned the second and third highest grand means. Job fair ended up fourth (with high standard deviation), and activities/tasks related to personal development were associated with the lowest grand means.

\section{Discussion}

By developing a career skills course for dental students, we wished to address a simple but important problem: 


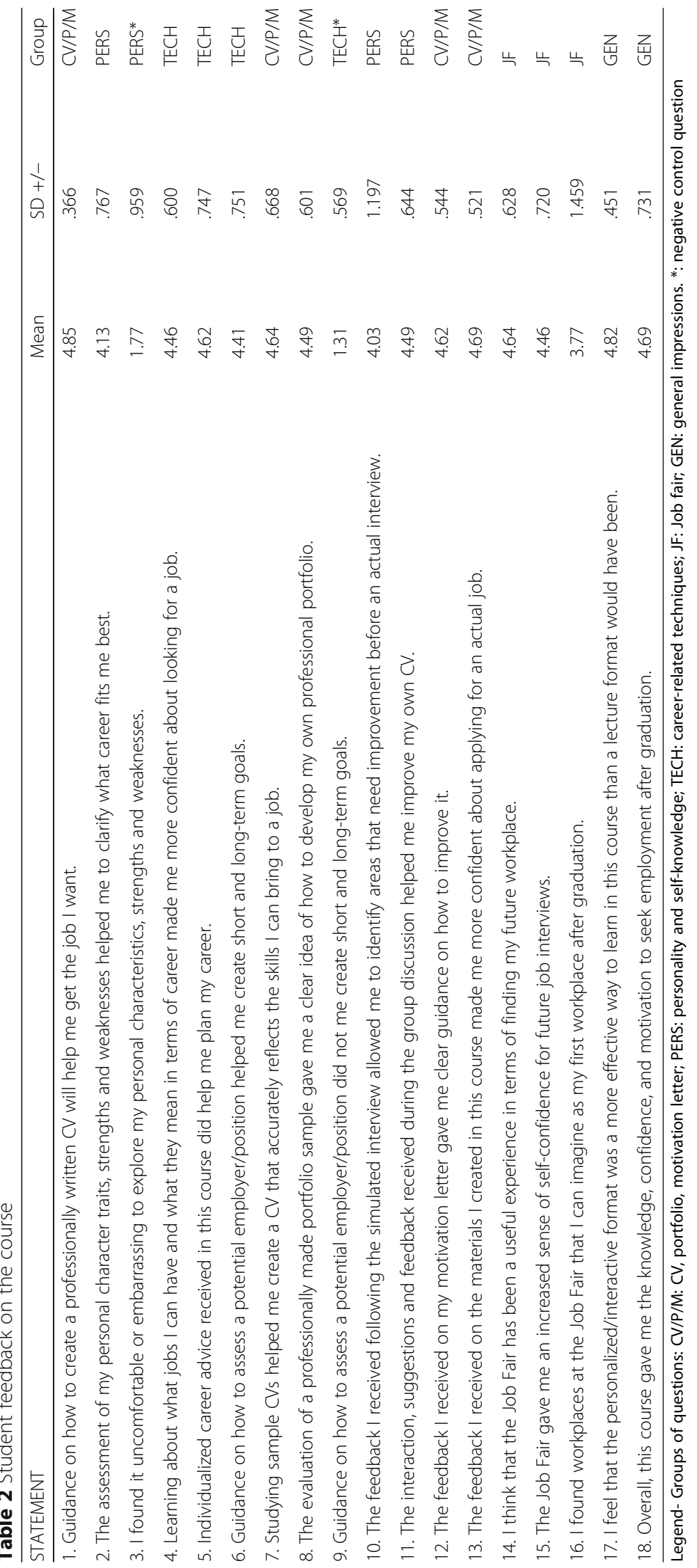




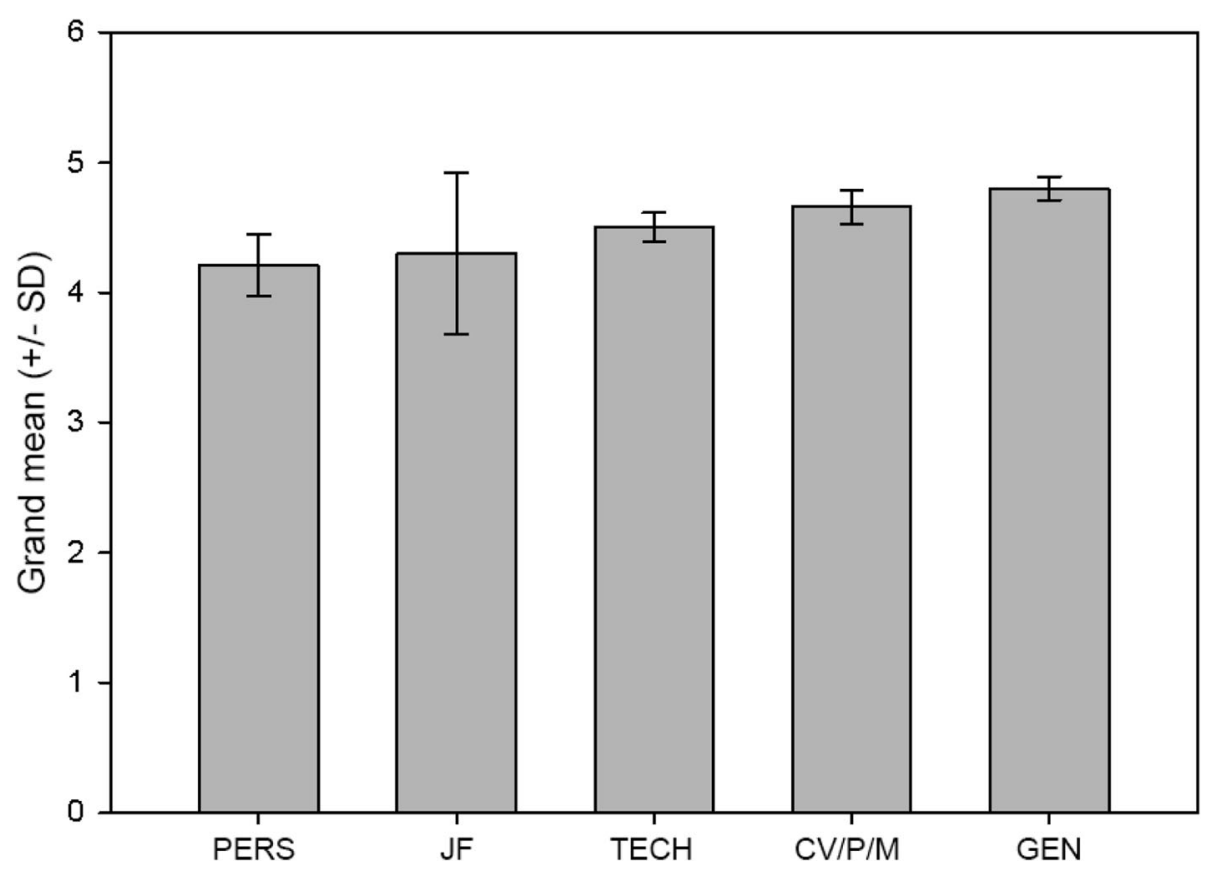

Fig. 2 Results of the aspect-wise analysis. Bars represent grand means, error bars represent \pm SD. The abbreviations are the same as in Table 2

in our teacher- and academic knowledge-centered system of dental education, the newly graduated dentist often finds that at the university, he/she learned the entire profession, but got little knowledge on how to reflect on himself/herself as a professional or as someone who is about to start a career. The lack of career skills and a concept of oneself within the profession may lead to mistaken career choices and secondary job dissatisfaction, which ultimately leads to burnout, and the individual gets stuck in a situation that leads to a severe deterioration of quality of life. This is not unique to dentistry, but - as outlined in the introduction - dentistry is a particularly stressful profession. Unfortunately, this is true not only for chairside work; being a dental teacher [30] or a dental leader [31] can be the source of just as much stress. We propose that being conscious about one's professional self, making conscious career choices, and having a sound knowledge of one's possibilities with a degree in dentistry (i.e., mobility) can serve as important coping resources.

We considered it to be of crucial importance to introduce this course as curricular with a credit value. There are two main reasons for this. First - even if it is not a mandatory course -, if a course is curricular, it carries the message that the faculty considers its contents related to the profession. Second, a credit value means that the student is rewarded for participation also in terms of progress in his/her studies. This latter aspect is important because students in our dental school are on an especially tight schedule in their final year, and they carefully assess the cost- benefit ratio of any subject they take. Therefore, it is possible that they do not take an optional course they would otherwise consider interesting or useful. With this format (optional curricular course for credit), we reached an above-average number of participants for a final-year optional course in the Hungarian group and average participation in the English-speaking group. The reason for the latter is probably that only a fraction of our English-speaking students are interested in Hungarian career options, those who wish to stay in Hungary for practice or specialization after graduation. This observation tells us that the English part of the course needs to be finetuned so that it can address a wider range of our English-speaking students.

Our hypotheses, described above, were mostly supported by the results. Students were highly satisfied with the course, and practical aspects $(\mathrm{CV}$, motivation letter, etc.) were among the highest-rated ones. According to the item-wise analysis, the most appreciated features of the course were its interactivit (item \#17; 4.82 \pm .451 ) and the chance to learn how to write a $\mathrm{CV}$ properly (item\#1; $4.85 \pm .366$ ). Of the five items obtained the highest scores, three were related to practical matters and two assessed general satisfaction. The item received the lowest score was \#16 ("I found workplaces at the Job Fair that I can imagine as my first workplace after graduation."). This came as no surprise, as the job fair offers a rather narrow, strictly local sample of employment possibilities. Some may find a job here, but it is 
more a training site where students can practice meeting employers without the usual real-life risks. Apart from this, the job fair scored high, as item \#14 ("I think that the Job Fair has been a useful experience in terms of finding my future workplace.") received a score of $4.64 \pm .628$. Items related to personal characteristics/personal growth, however, tended to obtain lower scores. This result might reflect the fact that Hungarian students (or students studying in Hungarian higher education) are not used to being given the chance to look at themselves as significant actors in a university course, as mentioned in the introduction. Therefore, the scores do not reflect dissatisfaction, but rather the unusualness of the situation. This result may also reflect that it is more difficult to assess the use of self-knowledge and various psychological skills than that of a $\mathrm{CV}$ or a motivation letter. A further possibility is that statements like "The assessment of my personal character traits, strengths and weaknesses helped me to clarify what career fits me best." (item \#2) are just too difficult to score shortly after the course, as such changes probably take more time. In this sense, the results may simply reflect the inaccurate wording of the corresponding item, which prompts us to revise these items before further use. The results of the aspect-wise analysis (Fig. 2) corroborate these findings.

Most importantly, our student-centered course worked surprisingly well in a traditionally teacher-centered educational environment, where university students are rarely encouraged to be active participants in courses. This is in contrast with the results of studies describing the difficulties of introducing student-centered elements in teacher-centered curricula $[32,33]$. We propose that the success of the course can be traced back to a few key factors. The first of these is the very subject of the course and its place in the curriculum. It is known that the opportunity to formulate meaningful personal learning objectives is a way to engage students in deep learning processes $[16,34,35]$. To senior students, starting a career is indeed an immediate and real personal goal, and working toward that goal is a logical and meaningful objective. Students of the lower grades would probably have found the course less engaging. The second factor is obviously the credit value of the course, through which the course did not only provide the students with important and personally meaningful skills, but also helped them toward finishing their studies. Third, the course was designed and offered by faculty members who were dedicated to the idea of student-centered education, which excluded the problem of faculty reluctance.

It is certainly a weakness of this study that the present instruments allow the assessment of short-term effects and impressions only. For a more accurate and less subjective assessment, we are planning add tests to measure various aspects of career readiness, like Hur and colleagues did in their study of medical students [25]. Finally, we cannot determine at the moment how lasting the effect of the course is. To answer that question, follow-up needs to be organized.

It is certainly a weakness of this study that the present instruments allow the assessment of short-term effects and impressions only. For a more accurate and less subjective assessment, we are planning add tests to measure various aspects of career readiness, like Hur and colleagues did in their study of medical students [25]. Finally, we cannot determine at the moment how lasting the effect of the course is. To answer that question, follow-up needs to be organized.

\section{Conclusions}

While it is quite common for universities to offer career skills trainings for undergraduate students, to our knowledge, no other university offers a curricular course of this kind, tailored especially to the needs of dental students. To our knowledge, the closest example is embedded counseling model described by Adams [36], but that model is more focused on students' problems while still at school than their future career.

By sharing our experience, we would like to highlight benefits of formal instruction in career planning skills. Our experience suggests that such a course can be implemented in a teacher-centered educational environment with relative ease, provided that a few conditions are fulfilled. First, the course should be offered toward the end of the curriculum, so that it offers a real, meaningful, personally important goal to the students. To first-year students, for instance, starting a career is a distant issue, and they will probably take the course primarily for its credit value. That way, due to the low level of engagement, little or no transfer happens, and the students will not have the skills and knowledge at their disposal when actually needed. Second, the course must be a curricular one, possibly with a credit value, to encourage enrollment and active participation. Third, it is important that the faculty responsible for such a course have knowledge of and be dedicated to student-centered methods. If such faculty is not available, it is worth considering the findings of Kim and Hwang [37], who identified three main characteristics of medical teachers who use student-centered methods. They found that basic sciences faculty, those with more teaching experience and those who are more knowledgeable about the school's educational objectives show less resistance to these methods and use them more frequently. This also carries the very important message that teaching the faculty about the educational objectives of the school is a way to increase readiness to change and openness to the student-centered approach. 
In summary, the success of our course shows that the often-mentioned difficulty with introducing studentcenteredness in a teacher-centered environment can be overcome even in a post-socialist country where the rigidity of higher education is still a problem. The application of such methods, however, requires the careful selection of the subject, the target group and the faculty.

\section{Abbreviations}

CV: Curriculum vitae; CV/P/M: Curriculum vitae, portfolio, motivation letter; DMD: Doctor of Dental Medicine; EU: European Union; GEN: general impressions; JF: Job fair; PERS: personality and self-knowledge; PhD: Doctor of Philosophy; TECH: career-related techniques

\section{Acknowledgments}

The authors would like to express their gratitude to Dr. Gábor Braunitzer for his critical comments on the manuscript.

\section{Authors' contributions}

RMS (Réka Magdolna Szabó) and MA (Mark Antal) developed and taught the course and drafted the manuscript; RMS and JMD (Joan Mary Davis). developed the course assessment questionnaire, administered it and analyzed the results; MA prepared the figures and Tables. JMD reviewed, corrected and finalized the manuscript. All authors have read and approved the final manuscript.

\section{Funding}

The course described in this study was developed in the framework of the grant EFOP-3.4.3 ("Developments in Institutions of Higher Education to Enhance the Quality and Accessibility of Higher Education"). The study itself was not funded by this grant and did not receive any funding from any organizations, governmental or private.

\section{Availability of data and materials}

The datasets used and/or analyzed in this study are available from the corresponding author on reasonable request.

\section{Ethics approval and consent to participate}

The study was approved by the Human Ethics Review Board of the University of Szeged (approval No. 41/2018), and the study design conformed in all respects to the Declaration of Helsinki. Written informed consent was obtained from all participants.

\section{Consent for publication}

Not applicable

\section{Competing interests}

The authors declare that they have no competing interests.

\section{Author details}

'Department of Health Economics, University of Szeged, Faculty of Medicine, Tisza Lajos körút 109, Szeged 6725, Hungary. ${ }^{2}$ Missouri School of Dentistry \& Oral Health, A.T. Still University, 1500 Park, St Louis, Missouri 63501, USA. ${ }^{3}$ Department of Esthetic and Operative Dentistry, University of Szeged, Faculty of Dentistry, Tisza Lajos körút 64, Szeged 6720, Hungary.

Received: 10 February 2019 Accepted: 24 February 2020 Published online: 06 March 2020

\section{References}

1. Macy Study T, Formicola AJ, Bailit HL, Beazoglou TJ, Tedesco LA Introduction to the Macy study report. J Dent Educ. 2008;72(2 Suppl):5-9.

2. Myers HL, Myers LB. 'It's difficult being a dentist': stress and health in the general dental practitioner. Br Dent J 2004; 197(2):89-93; discussion 83; quiz 100-101.

3. Leggat PA, Kedjarune U. Bacterial aerosols in the dental clinic: a review. Int Dent J. 2001;51(1):39-44.

4. Younai FS. Health care-associated transmission of hepatitis B \& C viruses in dental care (dentistry). Clin Liver Dis. 2010;14(1):93-104 ix.
5. Alexopoulos EC, Stathi IC, Charizani F. Prevalence of musculoskeletal disorders in dentists. BMC Musculoskelet Disord. 2004:5:16.

6. Rubel DM, Watchorn RB. Allergic contact dermatitis in dentistry. Australas J Dermatol. 2000;41(2):63-9 quiz 70-61.

7. Hyson JM Jr. The air turbine and hearing loss: are dentists at risk? J Am Dent Assoc. 2002:133(12):1639-42.

8. Puriene A, Aleksejuniene J, Petrauskiene J, Balciuniene I, Janulyte V. Occupational effects on the family well-being of dentists in Lithuania: a survey of dentists. Medicina (Kaunas). 2011;47(7):399-404.

9. Chuenjitwongsa S, Oliver RG, Bullock AD. Developing educators of European undergraduate dental students: towards an agreed curriculum. Eur J Dent Educ. 2018;22(3):179-91.

10. Newton JT, Mistry K, Patel A, Patel P, Perkins M, Saeed K, Smith C. Stress in dental specialists: a comparison of six clinical dental specialties. Prim Dent Care. 2002:9(3):100-4.

11. Winwood PC, Winefield AH, Lushington K. The role of occupational stress in the maladaptive use of alcohol by dentists: a study of south Australian general dental practitioners. Aust Dent J. 2003;48(2):102-9.

12. Gorter RC, Eijkman MA, Hoogstraten J. A career counseling program for dentists: effects on burnout. Patient Educ Couns. 2001;43(1):23-30.

13. Alexander RE. Stress-related suicide by dentists and other health care workers. Fact or folklore? J Am Dent Assoc. 2001;132(6):786-94.

14. Cerych L. Renewal of central European higher education: issues and challenges. Eur J Ed. 1990;25(4):351-9.

15. Ertmer PA. Addressing first- and second-order barriers to change: strategies for technology integration. Ed Tech Res Res Dev. 1999;47(4):47-61.

16. Hoidn S. The pedagogical concept of student-centered learning in the context of European higher education reforms. Eur Sci J. 2016;12(28): 439-58.

17. Bassir SH, Sadr-Eshkevari P, Amirikhorheh S, Karimbux NY. Problem-based learning in dental education: a systematic review of the literature. J Dent Educ. 2014;78(1):98-109.

18. Liu N, Littlewood W. Why do many students appear reluctant to participate in classroom learning discourse? System. 1997;25:371-84.

19. Jain A, Bansal R, Singh K, Kumar A. Attitude of medical and dental first year students towards teaching methods in a medical college of northern India. J Clin Diagn Res. 2014;8(12):XC05-8.

20. Alvarez S, Schultz JH. A communication-focused curriculum for dental students - an experiential training approach. BMC Med Educ. 2018;18(1):55.

21. Alrahlah A. How effective the problem-based learning (PBL) in dental education. A critical review. Saudi Dent J. 2016;28(4):155-61.

22. Fincham $A G$, Shuler CF. The changing face of dental education: the impact of PBL. J Dent Educ. 2001;65(5):406-21.

23. Super D. A life-span, life-space approach to career development. J Vocat Behav. 1980;16:282-98.

24. Super D. A theory of vocational development. Am Psychol. 1953;8(5):185-90.

25. Hur Y, Cho AR, Kim S. How to provide tailored career coaching for medical students. Korean J Med Educ. 2015;27(1):45-50.

26. Dipboye R. Selection interviews: process perspectives Mason. Thomson South-Western: OH; 1994.

27. Tross S, Maurer T. The effect of coaching interviewees on subsequent interview performance in structured experiencebased interviews. J Occup Organ Psychol. 2008;81:589-605.

28. Maurer T, Solamon J, Troxtel D. Relationship of coaching with performance in situational employment interviews. J Appl Psychol. 1998;83(1):128-36.

29. Maurer TJ, Solamon JM, Andrews KD, Troxtel DD. Interviewee coaching, preparation strategies, and response strategies in relation to performance in situational employment interviews: an extension of Maurer, Solamon, and Troxtel (1998). J Appl Psychol. 2001;86(4):709-17.

30. Rutter H, Herzberg J, Paice E. Stress in doctors and dentists who teach. Med Educ. 2002;36(6):543-9.

31. Tuononen $\mathrm{T}$, Suominen AL, Lammintakanen J. Factors associated with staying or leaving a dentist leader's position - a qualitative study. BMC Oral Health. 2016;16:50

32. Frambach JM, Driessen EW, Chan LC, van der Vleuten CP. Rethinking the globalisation of problem-based learning: how culture challenges selfdirected learning. Med Educ. 2012;46(8):738-47.

33. Waterval D, Tinnemans-Adriaanse M, Meziani M, Driessen E, Scherpbier A, Mazrou A, Frambach J. Exporting a student-centered curriculum: a home Institution's perspective. J Stud Int Educ. 2017;21(3):278-90. 
34. Maclellan E. The significance of motivation in student-centered learning: a reflective case study. Teach High Ed. 2008;13(4):411-21.

35. Pintrich P, Schunk D. Motivation in education. Prentice-Hall Merrill: Upper Saddle River, NJ; 2002

36. Adams DF. The embedded counseling model: an application to dental students. J Dent Educ. 2017:81(1):29-35.

37. Kim KJ, Hwang JY. Characteristics of medical teachers using studentcentered teaching methods. Korean J Med Educ. 2017;29(3):187-91.

\section{Publisher's Note}

Springer Nature remains neutral with regard to jurisdictional claims in published maps and institutional affiliations.

Ready to submit your research? Choose BMC and benefit from:

- fast, convenient online submission

- thorough peer review by experienced researchers in your field

- rapid publication on acceptance

- support for research data, including large and complex data types

- gold Open Access which fosters wider collaboration and increased citations

- maximum visibility for your research: over $100 \mathrm{M}$ website views per year

At $\mathrm{BMC}$, research is always in progress.

Learn more biomedcentral.com/submissions 